\title{
THE RELATIONSHIP BETWEEN DISCIPLINE AND EMOTIONAL INTELLIGENCE TOWARDS EMPLOYEE PERFORMANCE
}

\author{
Hubungan Disiplin dan Kecerdasan Emosional terhadap Kinerja Pegawai \\ ${ }^{*}$ Dian Rosa Linda 1 , Puji Astuti², Satriya Wijaya ${ }^{3}$ \\ ${ }^{1,3}$ Faculty of Health Science, Nahdlatul Ulama Surabaya University, Surabaya, Indonesia \\ ${ }^{2}$ Faculty of Nursing and Midwifery, Nahdlatul Ulama Surabaya University, Surabaya, Indonesia \\ ${ }^{*}$ Correspondence: dian.km14@student.unusa.ac.id
}

\begin{abstract}
Background: One of problems in an organization or company is poor performance of employees. For instance, they do not complete tasks or finish their job responsibilities on time. The preliminary data taken from one of companies in Surabaya showed that 184 employees did not come to work without any explanations, and 288 employees worked late.

Aim: This study analyzed the relationships between discipline and emotional intelligence towards employee performance at the company.

Method: The design of this research was analytical using a cross sectional approach. The population of this study was employees at Production and Maintenance Section of one company in Surabaya comprising of 155 people. Out of 155 employees, 89 respondents were taken as samples using a stratified random sampling technique. Then, the data were collected through a questionnaire and analyzed using Spearman's rank correlation test with a significance level of $\alpha 0.05$.

Results: This study showed that most of the respondents were very highly disciplined (94.4\%) and had a highly emotional intelligence (74.2\%). Lastly, most of them perform satisfyingly $(50.6 \%)$. The results of the analysis test with Spearman's rank correlation yielded p-value of $0.002<\alpha 0.05$. It means there was a correlation between discipline attitude and employee performance. The $p$-value 0.001 which was less than $\alpha$-value of 0.05 showed that there was a correlation between emotional intelligence and employee performance.

Conclusion: Discipline and emotional intelligence are prominent to determine employee performance at PT X. In order to improve the discipline and intelligence in the performance of the employees, the company should provide rewards based on employee's achievements in the workplace.
\end{abstract}

Key words: Emotional intelligence, Employee performance, Discipline.

\begin{abstract}
ABSTRAK
Latar Belakang: Salah satu permasalahan yang dapat terjadi pada sebuah organisasi atau perusahaan yaitu masalah kinerja yang buruk misalnya, tidak tepat waktu dalam menyelesaikan tugas dan tanggung jawab pekerjaan pekerjaan. Hasil observasi data awal pada karyawan PT.X diperoleh 184 karyawan tidak masuk kerja tanpa keterangan, dan 288 karyawan datan terlambat.

Tujuan: Tujuan penelitian ini untuk menganalisis hubungan kedisiplinan dan kecerdasan emosional terhadap kinerja pada karyawan PT.X.

Metode: Desain penelitian ini adalah analitik dengan pendekatan cross sectional. Populasi dalam peneltian ini adalah karyawan bagian produksi dan pemeliharaan sebesar 155 orang. Besar sampel adalah 89 responden diambil dengan teknik stratified random sampling. Pengumpulan data penelitian menggunakan lembar kuesioner. Analisis data menggunakan uji statistik korelasi rank spaerman dengan tingkat kemaknaan sebesar $\alpha 0.05$.

Hasil: Hasil penelitian menunjukkan bahwa karyawan PT.X, hampir seluruhnya (94,4\%) memiliki kedisiplinan sangat tinggi, sebagian besar (74,2\%) memiliki kecerdasan emosional tinggi. Sebagian besar pegawai $(50,6 \%)$ menunjukkan kinerja memuaskan. Hasil uji analisis dengan korelasi rank Spearman diperoleh nilai p 0,002 < $\alpha$ 0,05. Hal ini bermakna bahwa terdapat hubungan antara kedisiplinan dan kinerja karyawan. Nilai p 0,001 kurang dari nilai $\alpha$ 0,05, artinya terdapat hubungan antara kecerdasan emosional dengan kinerja karyawan.
\end{abstract}


Kesimpulan: Disiplin dan kecerdasan emosional penting dalam menentukan kinerja pegawai di $P T X$. Guna meningkatkan kedisiplinan dan kecerdasan dalam kinerja karyawan sebaiknya perusahaan memberikan reward sesuai dengan prestasi di tempat kerja.

Kata Kunci: Kecerdasan Emosional, Kinerja pegawai, Kedisiplinan

Received: 9 January 2019

Accepted: 7 May 2019

Published: 23 September 2019

\section{INTRODUCTION}

Company success depends on its employees; consequently, a company demands employees to perform optimally since their performance will affect the company as a whole. Employee's achievements are performances assessed in terms of quality or quantity based on the standard job descriptions determined by the organization. Good performance means appropriate performance based on the standards of organizations which support the business goals (Mangkunegara, 2014). Meanwhile, empirically there are many problems in the management of human resources by an organization or company that can lead to bad employee's performance. For example, employees are not able to complete their duties properly. For instance, this water company studied from January to June could only produce an average amount of $4,949,519 \mathrm{~m}^{3}$, far from the predetermined plan of $5,212,800 \mathrm{~m}^{3}$.

Employee performance is affected by various factors, such as job satisfaction, communication, work practice, leadership, discipline, competency, and other factors in a workplace (Kasim, Rantetampang and Lumbantobing, 2016). In addition, factors that affect employee performance are expectations about rewards, encouragement, rewards, and internal perceptions of tasks (Moeheriono, 2012). Furthermore, according to Mathis and Jackson (2009), performance is also affected by other factors, such as individual's intelligence, individual efforts, and support from the organizations. In fact, a company sometimes cannot reach its planning. This study focused on analyzing the relationship between discipline and emotional intelligence towards employee performance at the company.

\section{METHOD}

The study design was an analytical study using a cross-sectional approach. The population of this study was 155 employees who work in the Production and Maintenance Section of one company in Surabaya. Out of 155 employees, only 89 respondents were selected as the samples using a stratified random sampling technique. The data collection was conducted through a questionnaire, and the data were tested using the Spearman rank correlation test with a significance level of $\alpha 0.05$.

\section{RESULTS AND DISCUSSION}

\section{Discipline}

The results showed that almost all employees (94.4\%) had very good discipline attitude. The employees with excellent discipline attitude can be seen from the questionnaire with the highest answer percentage of $99.2 \%$ for item 1. It required the employees to be on time according to the working hours. Based on the observations, the company uses a finger-print attendance system in which all attendances are recapitulated. Thus, it will be easily known when the employees violate the work hours. In addition, there are penalties for employees who are not disciplined in the forms of three written warnings.

Factors that influence employee discipline include compensation, exemplary leadership in the company, decisiveness in decision-making, attention to employees, and sactions (Sutrisno, 2010). The results of this study is in line with the research conducted by Sianipar (2017), stating that factors which influence employee discipline include compensation, exemplary leadership, decisive leadership, and punishment (Sianipar, 2017).

Based on Table 2, almost all employees (94.4\%) in the Production and Maintenance Section of the company have very good discipline.

Table 1. Discipline Level of Employees in the Production and Maintenance Section of the Company.

\begin{tabular}{clrc}
\hline No. & Discipline & Frequency & $\begin{array}{c}\text { Percentage } \\
(\%)\end{array}$ \\
\hline 1. & Very Good & 84 & 94.4 \\
2. & Good & 5 & 5.6 \\
3. & Sufficient & 0 & 0.0 \\
4. & Insufficient & 0 & 0.0 \\
5. & Not Good & 0 & 0.0 \\
\hline & Total & 89 & 100.0 \\
\hline
\end{tabular}

Source: Primary Data, 2018

\section{Emotional Intelligence}

The results showed that most of the respondents $(74.2 \%)$ had a high emotional intelligence as explained in Table 2. Also, they had a good emotional maturity since they were able to manage or regulate their emotions well, give a quick signal to every emotion, motivate themselves not to complain or give up, and understand the emotions of others, so they could 


\section{[1]JAKI \\ IURNAL ADMINISTRASS
KESHATATAN INDONESIA \\ INDONESLAN LOURNAL of}

treat others well. Besides, they were able to create a good relationship with their colleagues and their environment.

This is relevant to Goleman's theory which stated that emotional intelligence is the ability to recognize his or her own feelings and others' in order to motivate him/herself and manage emotions well inside his/her own body and in his/her relationships (Goleman, 2009). Emotional maturity is very important, especially for employees because having a good emotional maturity will make them able to control deviant behaviors (Guswani, 2011).

Table 2. Emotional Intelligence of Employees in the Production and Maintenance Section of the Company

\begin{tabular}{cccc}
\hline No. & $\begin{array}{c}\text { Emotional } \\
\text { Intelligence }\end{array}$ & Frequency & $\begin{array}{c}\text { Percentage } \\
(\%)\end{array}$ \\
\hline 1. & Very High & 20 & 3.4 \\
2. & High & 66 & 74.2 \\
3. & Average & 3 & 3.4 \\
4. & Low & 0 & 0.0 \\
5. & Very Low & 0 & 0.0 \\
\hline & Total & 89 & 100.0 \\
\hline
\end{tabular}

\section{Performance}

In addition to discipline and emotional intelligence, most of the respondents $(50.6 \%)$ had satisfactory performances as seen in Table 3 . It can be seen from the questionnaire answers for item 6. Questionnaire number 6 says that employees are able to work with their colleagues.

Team work can be seen from the presence of two or more people who interact with each other and work together by prioritizing communication and building trust among members in the workplace. Also, it means being responsible for the results to produce excellent performances to achieve goals and objectives. The goals can be easily attained because the employees in every sia Volume 7 Supplement 12019

Published by Universitas Airlangga

Doi: 10.20473/jaki.v7i1.2019.11-15

section have ongoing and optimal team work. Hence, it affects how the employees resolve a task more quickly to accomplish the vision of the company and consumers (Pratiwi and Nugrohoseno, 2014).

Table 3. Employee Performance in the Production and Maintenance Section of the Company.

\begin{tabular}{clcc}
\hline No. & Performance & Frequency & $\begin{array}{c}\text { Percentage } \\
(\%)\end{array}$ \\
\hline 1. & Very & 42 & 47.2 \\
& Satisfying & & \\
2. & Satisfying & 45 & 50.6 \\
3. & Standard & 2 & 2.2 \\
4. & Need & 0 & 0.0 \\
& Improvement & & 0.0 \\
5. & Not & 0 & \\
$\quad$ Acceptable & & 100.0 \\
\hline \multicolumn{2}{l}{ Total } & 89 &
\end{tabular}

\section{Relationship between Discipline and Performance}

Table 4 showed that when an employee has a better discipline, their performance will be more satisfying. Based on the Spearman's rank correlation test, p-value obtained was 0.002 with a significance level of 0.05 . Because $p$-value $(0.002)$ is less than $\alpha$-value $(0.05)$, it means that $\mathrm{HO}$ is rejected; it indicated that there was a significant relationship between discipline and employee performance in the Production and Maintenance Section of the Company. Then, the correlation coefficient value was 0.319 , meaning that the relationship level between discipline and employee discipline was quite strong.

The employees have a high perception of discipline with the total percentage of $97.1 \%$. Penalties for the employees who violate the company regulations may be the reason, and there is an inherent supervision from the company leaders.

Table 4. Relationship between Discipline with Employee Performance in the Production and Maintenance Section of the Company.

\begin{tabular}{|c|c|c|c|c|c|c|c|c|c|}
\hline \multirow{3}{*}{ No. } & \multirow{3}{*}{ Work Discipline } & \multicolumn{6}{|c|}{ Performance } & \multicolumn{2}{|c|}{ Total } \\
\hline & & \multicolumn{2}{|c|}{ Standard } & \multicolumn{2}{|c|}{ Satisfy } & \multicolumn{2}{|c|}{ Very Satisfy } & \multirow[b]{2}{*}{$\mathbf{n}$} & \multirow{2}{*}{$\%$} \\
\hline & & n & $\%$ & $\mathbf{n}$ & $\%$ & $\mathrm{n}$ & $\%$ & & \\
\hline 1. & Good & 2 & 40 & 3 & 60 & 0 & 0 & 5 & 100 \\
\hline 2. & Very Good & 0 & 0 & 42 & 50 & 42 & 50 & 84 & 100 \\
\hline Total & & 2 & 2.2 & 45 & 50.6 & 42 & 47.2 & 89 & 100 \\
\hline \multicolumn{10}{|c|}{ Spearman's Rank Correlation Test } \\
\hline \multicolumn{4}{|c|}{ Correlation Coefficient } & \multicolumn{4}{|c|}{ p-value } & & \\
\hline \multicolumn{4}{|c|}{0.319} & \multicolumn{4}{|c|}{0.002} & & \\
\hline
\end{tabular}

The results of this study are similar to the research conducted by Sutrisnoputri (2018). It found that discipline is significantly related to employee performance. Similarly, Kasim (2016) revealed that there was a significant relationship between discipline and the performance of the administrative staffs at Abepura Hospital in Papua with $p$-value of 0.0312 .

Like Colquit's theory (2009), employee performance is a set of employee behavioral values that contribute positively or negatively to company goals. In terms of perspective, 
performance includes two elements, namely individual perspective and organizational perspective. In the organizational perspective, performance is defined as the value created by an organization which uses its productive assets to achieve its expectation. Whereas, the individual

\section{Relationship between Emotional Intelligence and Employee Performance}

The situation presented in Table 4 was related to the situation in Table 5 . Based on the Spearman's rank correlation test, $p$-value was 0.001 with $\alpha$-value of 0.05 . Since $p$-value $(0.001)$ is less than sig. a (0.05), it means that $\mathrm{HO}$ is rejected; It indicates there is a significant relationship between emotional intelligence and employee performance in the Production and Maintenance Section of the company. Furthermore, the correlation coefficient was 0.446, meaning that their relationship is fairly close.

Overall, the employees in the company had a high perception of emotional intelligence at $78.9 \%$. It was assumed that because the respondents already had good emotional maturity, they could manage their emotions well and had empathy for others. Wibowo (2015) has similar findings of this study which showed there was a significant effect between the emotional intelligence and employee performance of PT. Bank Negara Indonesia with p-value of 0.000 and perspective defines performance as the ability to perform some work formally approved as a part of his work, in which a series of activities aim to achieve targets with several standards of organizational expectations within a certain period of time (Jeffrey and Ruliyanto, 2017).

$\alpha$ of 0.05 . This means that the higher the emotional intelligence is, the better the employee performance is.

The results also had the same ideas as Hidayati (2008) found that emotion plays a major role in "rational" decision-making. High emotional intelligence will help individuals deal appropriately with conflicts and create a comfortable working condition to produce excellent performance. Conversely, low emotional intelligence will have a negative impact on employee performancebecause individuals are less able to make rational decisions and appropriately deal with conflicts. Emotional intelligence also allows employees to achieve their goals. Self-awareness, self-mastery, empathy, motivation, and good social skills are the abilities that strongly support the employees to accomplish challenging work and competition among colleagues. Therefore, it can be said that emotional intelligence is necessary for every employee to improve his or her performance (Hidayati, Purwanto and Yuwono, 2008).

Table 5. Relationship between Emotional Intelligence and Employee Performance in the Production and Maintenance Section of the Company.

\begin{tabular}{|c|c|c|c|c|c|c|c|c|c|}
\hline \multirow{3}{*}{ No } & \multirow{3}{*}{ Emotional Intelligence } & \multicolumn{6}{|c|}{ Performance } & \multicolumn{2}{|c|}{ Total } \\
\hline & & \multicolumn{2}{|c|}{ Standard } & \multicolumn{2}{|c|}{ Satisfy } & \multicolumn{2}{|c|}{ Very Satisfy } & \multirow{2}{*}{$\mathbf{n}$} & \multirow{2}{*}{$\%$} \\
\hline & & $\mathbf{n}$ & $\%$ & $\mathbf{n}$ & $\%$ & $\mathbf{n}$ & $\%$ & & \\
\hline 1. & Average & 1 & 33.3 & 2 & 66.7 & 0 & 0 & 3 & 100 \\
\hline 2. & High & 1 & 1.5 & 40 & 60.6 & 25 & 37.9 & 66 & 100 \\
\hline 3. & Very High & 0 & 0 & 3 & 15 & 17 & 85 & 20 & 100 \\
\hline Total & & 2 & 2.2 & 45 & 50.6 & 42 & 47.2 & 89 & 100 \\
\hline \multicolumn{10}{|c|}{ Spearman's Rank Correlation Test } \\
\hline \multicolumn{3}{|c|}{ Correlation Coefficient } & \multicolumn{7}{|c|}{$\mathrm{p}$-value } \\
\hline \multicolumn{3}{|c|}{0.319} & \multicolumn{7}{|c|}{0.002} \\
\hline
\end{tabular}

\section{CONCLUSION}

Based on the findings, the majority of employees in the company had very good discipline and high emotional intelligence. Most of them also had satisfying performances and could control their emotions. There was a significant relationship between discipline and employee performance with quite strong relationship. Moreover, both discipline and employee performance have unidirectional relationships. It means that the higher the discipline is, the better the performance is.

Furthermore, there was a significant relationship between emotional intelligence and employee performance with quite strong relationship. They also have unidirectional relationship which means the higher the emotional intelligence is, the better the performance is. To recommend, the company should give a reward to the employees who have excellent performance.

\section{REFERENCES}

Goleman, D. (2009) Kecerdasan Emosional: Mengapa El Lebih Penting Daripada IQ. Jakarta: PT. Gramedia Pustaka Utama.

Guswani, A. (2011) 'Perilaku Agresi pada Mahasiswa Ditinjau dari Kematangan Emosi', Jurnal Psikologi Pitutur, 1(2), pp. 8692.

Hidayati, R., Purwanto, Y. and Yuwono, S. (2008) 'Kecerdasan Emosi, Stress Kerja dan Kinerja Karyawan', Jurnal Psikologi, 2(1), pp. 91-96.

Jeffrey, I. and Ruliyanto (2017) 'The Effect of Competence, Training and Work Discipline 
towards Employees ' Performance ( A Case Study at PT. Krakatau Argo Logistics )', International Journal of Business and Management Invention, 6(7), pp. 77-86.

Kasim, D., Rantetampang, A. L. and Lumbantobing, H. (2016) 'Relationships of Work Discipline , Leadership , Training , and Motivation to Performance of Employees Administration Abepura Hospital Papua 2015', Journal of Sciences: Basic and Applied Research, 26(1), pp. 154-164

Mangkunegara, A. P. (2014) Evaluasi Kineja SDM. Bandung: Refika Aditama.

Mathis, R. L. and Jackson, J. H. (2009) Manajemen Sumber Daya Manusia. Jakarta: Salemba Empat.

Moeheriono (2012) Pengukuran Kinerja Berbasis Kompetensi. Jakarta: Rajagrafindo Persada.

Pratiwi, W. K. and Nugrohoseno, D. (2014) 'Pengaruh Kepribadian Terhadap Kerjasama Tim dan Dampaknya Terhadap Kinerja Karyawan', Jurnal Bisnis dan Manajemen, 7(1), pp. 63-72.

Sianipar, P. A. (2017) 'Analisis Faktor-Faktor Kedisiplinan Kerja Karyawan pada Koperasi Tirta Dharma Khatulistiwa PDAM Kota Pontianak', Jurnal Pendidikan dan Pembelajaran, 6(8), pp. 1-12.

Sutrisno, E. (2010) Manajemen Sumber Daya Manusia. Jakarta: Kencana.

Wibowo (2015) Manajemen Kinerja. Jakarta: Rajawali Pers. 